\title{
Political Beliefs: Determinant Well-Being of the Flood Victims
}

\author{
Noor Hadzlida Ayob and Mohd Fo'ad Sakdan
}

\begin{abstract}
The degree of well-being and satisfaction that people experienced has an influence on their political beliefs. During times such as in natural disasters or catastrophe, the victims' senses of political beliefs are tested and can result in negative perceptions, a decline towards disbelief in their own politicians. However, during floods, the victims still seem to trust their own politicians.Although remedial strategies and relief may come from other parties, they still hold on to their political beliefs. Hence, this article attempts to investigate the political belief system of the flood victims and examine if it can indicate their political well-being.
\end{abstract}

Index Terms-Political beliefs, well-being, happiness, flood victims.

\section{INTRODUCTION}

In this paper we are looking at whether the political belief of victims of a natural disaster is affected due to the actions taken by political or interest groups. Political belief is defined by researchers in different ways based on different aspects. In [1], Jervis defined the word belief as having a strong commitment and faith. According to Dawson, political belief is a cognitive process by which individuals form organized beliefs about politics [2]. He further stated that the political beliefs are influenced by political events such as campaigns, meetings, introduction of policies and manifestoes. Wasserman approaches the political beliefs from a negative angle by defining political cynicism as the individual suspicions of government and its agencies [3]. From all the aforementioned definitions it can be understood that political belief is a strong commitment emerging through a cognitive process in individuals, making them lean towards a specific political party or a member of a party. This commitment has been affected by various factors such as partisanship and group coherence [4]. According to Wasserman, political cynicism has little or no impact on total life satisfaction. Since cynicism focuses more on the negative aspects, it may not fully explain the impact of positive beliefs on the satisfaction.

Hence, it is pertinent to investigate the effects of positive political beliefs on the perceived well-being of the people. In

Manuscript received May 25, 2013; revised July 23, 2013.This work was supported in part by the Long-Term Research Research Grant Scheme (LRGS) of the Ministry of Higher Education, Malaysia under Grant 12494.

Noor Hadzlida Ayobis a PhD candidateof the College of Government, Law and International Studies (COLGIS),Universiti Utara Malaysia, Sintok, Kedah DarulAman, Malaysia (e-mail: hadzli_ida09@yahoo.com).

Mohd Fo'ad Sakdanis an associate professor attached to the College of Government, Law and International Studies (COLGIS),Universiti Utara Malaysia. He is currently the Director of the Research and Innovation Management Center (RIMC) of the Universiti Utara Malaysia (e-mail: foad437@uum.edu.my). this study, we concentrate on a specific case of natural disaster victims with respect to their political beliefs and its effect on their perceived well-being. The victims of a recent natural disaster have been specifically selected as they have undergone a bad experience in terms of losses of life, property and livelihoods in some cases. So, they may have a different view about their well-being compared to others who did not undergo such experiences. In this study, we carried out a survey among the flood victims of the state of Kelantan in Malaysia on their views of their political beliefs and their perceived well-being in order to identify the relationship between them, if any.

This paper has been organized as follows. Section I introduces the paper. Section II consists of previous research related to this study, followed by the theoretical framework in section III. SectionIV deals with the methodology and section $\mathrm{V}$ contains the findings of the research. The last section is the conclusion and recommendation for further research.

\section{RELATED WORK}

Natural disasters such as floods, droughts and human hazards can have implications in human well-being [5]. However, Halpern also stated that efforts committed by the government, agencies, political parties or democratic institutions to reduce the impact of the catastrophic events will create trust and belief in the victims and simultaneously rise the degree of the life satisfaction among them [5].

This statement, which is parallel with the research conducted by [6] in investigating the impact of the privation of relief, will cause dissatisfaction amongst the Hurricane Betsy victims. However, the findings contrast with their hypothesis whereas the result indicates that the privation of relief does not have an impact in changing the victims' political beliefs. When the government still puts an effort to neutralize the disaster and other aspects related to politics, it will make the victims satisfied even with inadequate preparation from the government.

Arceneaux and Stein [7] asserted that the flood victims will give credit or blame the government based on their political knowledge. However, they also stated that not all the victims blame the government even though they have wide knowledge in politics. Due to this, they believed that a disaster or catastrophe is something that cannot be avoided. If the government puts an effort in assisting the flood victims, they will feel satisfied and continue to vote for the incumbents.

Vice versa, if there are no such efforts, less initiatives, late in providing relief by the government or supporting parties, it will affect the political well-being of the disaster victims. The Hurricane Katrina, for instance, indicated the dissatisfaction 
of the victims with the Bush leadership when he was late in announcing the disaster declarations [8]. The impact from that action seemed to disappoint the voters who disbelieved the incumbent government and would punish the president on the Election Day [8].

During disasters, the victim's sense of political belief seems tested and changeable. The victim's mechanisms of thoughtdepend on the psychological effect of their experience from the disaster [9]. In Hurricane Katrina,the victims tended to reward or punish the governor and president depending on the efforts and action taken by them. When a governor requested for a disaster declaration and it wasgiven by the president, voters responded with increasedsupport for those two onthe Election Day. However, when thegovernor requested for the disaster declaration and was refused by the president, in the next election the governor will be rewarded and the president will be punished in the ballot box [9].

In describing this phenomenon, Olson and Gawronski [10] described in more details about the consequences of the event based on " $5 \mathrm{C}+\mathrm{A}$ " dimension: capability, competence, compassion, correctness, credibility, and anticipation. Victims of disaster reward the authorities based on those six criteria and will punish the incumbent if they lack those six conditions. For instance, Olson and Gawronskimade a comparison between two disasters, namely the 9/11 tragedy in 2001 and the Hurricane Katrina in 2005 that increased Bush's public image and struck down his reputation based on the " $5 \mathrm{C}+\mathrm{A}$ " perspective.

In 9/11 tragedy, Bush seemed to delivereffective assistanceand highly responsive toward the disaster. These actions indicate the capability, competency and credibility of the Bush administration toward the tragedy. Additionally, his emotion in handling the tragedyalso indicates the compassion of Bush in solving the problem. Based on the 9/11 tragedy, Bush seemedto have encompassed the majority criteria of " $5 \mathrm{C}+\mathrm{A}$ " that enhancedhis reputation and image.

Four years later when the Hurricane Katrina occurred, it indicates contradicting actions from the Bush administration;slow in response and inefficient in delivering the relief making his administration lackingin all the " $5 \mathrm{C}+\mathrm{A}$ " criteria,resultingin the decrease of hisimage as the authority and the Republican party was punished in the next election [10]. The contradicting actions between the 9/11 tragedy and Hurricane Katrina made it clear that the public opinion value the authority based on the " $5 \mathrm{C}+\mathrm{A}$ " conditions.

Even though [10] has describedthe details about the criteria of " $5 \mathrm{C}+\mathrm{A}$ " to determine the public action in choosing the right authority, based on other literature it also depends on the circumstances of the authority in handling the problems. Reeves in [9] mentioned that despite the governor not being capable and competent in handling the Katrina disaster, his high compassion and effort to request for the disaster declaration was just enough for him to be rewarded in the next election. This is similar with the findings of [6] that indicate the privation of relief from the government or authority did not change the political beliefs of the victims toward their political party. They still hold their own beliefs if their politicians and political party put an effort and show compassion in neutralizing the disaster as well as counteringall the issues that are related to politics. This means in some circumstances, the capability and competence of the authority in the " $5 \mathrm{C}+\mathrm{A}$ " dimension cannot describe the real phenomenon of people satisfaction in changing their political beliefs.

Nevertheless, Olson and Gawronski already made it clear in two eventsoccurring in different time that indicate the capability and competency of Bush administration in neutralizinga big disaster such as $9 / 11$ but hewas unable to handle the Hurricane Katrina disaster. Therefore, the capability and competency in handling the two big catastrophes differently can be argued.

These issues may differ betweenthe government and authorities in the developing countries where the capabilities in neutralizing big disasters arevalued by their people. Countries such as Malaysia, Indonesia, Pakistan, and Bangladesh may not be capable in handling big disasters that occursimultaneously. Hence, the people were perceived to value the government based on their effort and compassion in neutralizing the disasters. To expect their government to handle catastrophic eventswith dynamic relief and early warning systemperfectly had never been experienced by the victims in the developing countries [11].Therefore, they tend to value their political party based on their hard work, effort and compassion of their politicians to help ease their burden [6], [9].

It seems that the victims' political well-being is not dependent on how much relief that they receiveor how capable or competent their politicians are in neutralizing the problems but it dependson how much the parties'or politicians' efforts and work in the heart of disaster area with their shirt sleeves rolled up.

\section{THEORETICAL FRAMEWORK}

Fig. 1 indicates the positive political beliefs on the perceived well-being of the people based on the theory of Cognitive Behavior Therapy [12]. Internal political beliefs and the external aspect such as political actions play major roles in creating the well-being of the people.

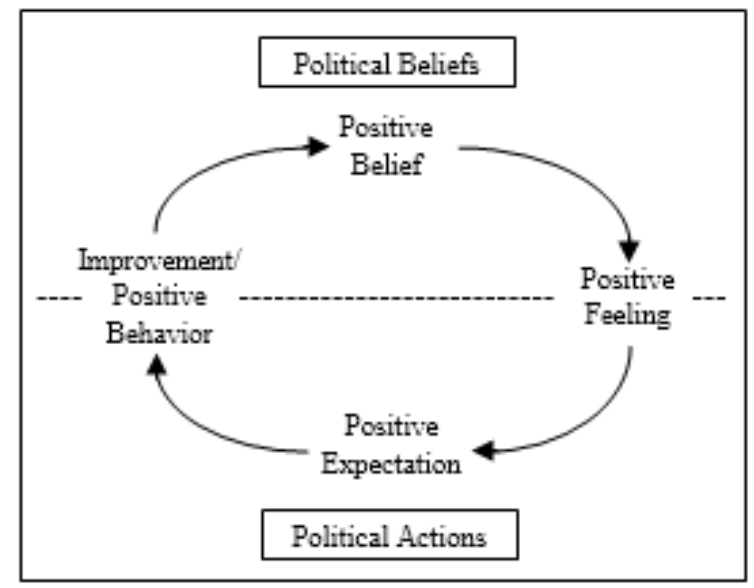

Fig. 1. Political beliefs as a function toward well-being.

Based on Fig. 1, positive political beliefs will create positive feeling toward the political parties or politicians. Those feelings will make people have positive expectations of their politicians. However, the expectations need to be supported by political actions. If the people have positive expectations of their supporting parties but the political 
actions contradict the expectations of the people, they may disbelieve their politicians or party. On the contrary, if the expectation sare supported by political actions such as efforts, compassion or endeavor of the politicians, it will create a positive behavior, improvement, satisfaction as well as enhance the well-being of the people.

This positive belief distinguishes from political cynicism, where people disbelieve and are suspicious of politics. Wasserman [3] found that political cynicism has no impact on the people's satisfaction, but positive beliefs may differ from negative beliefs. In order to enhance the well-being, it must start with positive beliefs and supported with political actions. However, the root of the well-being still comes from the positive beliefs; without positive beliefs or political cynicism, even when political actions play such a good role, it still cannot satisfy the people who have political cynicism [3]. Examining the positive political beliefs to determine the well-beingcan be observed in critical situations such as in a flood disaster.

\section{Methodology}

To measure the political beliefs in determining the well-being of the flood victims, a qualitative method with an interview approach was conducted among the respondents who have experienced flooding. Respondents from the state of Kelantan have been selected to be interviewed in February 2013 due to the flood disaster occurring then. Interviews were done at special evacuation centers in Sekolah Kebangsa an Gual Tinggi and Sekolah Kebangsaan Rantau Panjang II.

The placeswere selected because the areas were flood-prone and it was more convenient to get information from the flood victims because they stayed in the evacuation centers and researchers could find all the myriad political ideologies among them in the areas.

Two approaches were used in the data collection. The first approach was group discussion. The group discussion was chosen in order to determine the well-being of flood victims based on the relief that they received from several political parties. Selecting the group discussion approach in determining the types of relief received by the flood victims is to reduce the bias from the flood victims in answering about the relief they received. By doing so it also enhances the trustworthiness of the information gathered from several people with different ideologies in the group. The second approach was the main approach in this research in determining the political beliefs of individuals and attempting to relate it to their political well-being. The individuals were chosen by the purposive sampling based on the different political beliefs they had. A total of 12 respondents were interviewed in both evacuation centers; six from Sekolah Kebangsaan Gual Tinggi and the other six from Sekolah Kebangsaan Rantau Panjang II.

The data from the group discussions and individual interviews in both evacuation centers were recorded and analyzed in order to examine the political well-being of the victims and to determine whether the better relief that they received from the opposition parties can be tested in disbelieving their supporting party as well as decreasing their political well-being.

\section{FINDINGS AND DISCUSSION}

\section{A. Relief}

The group discussions in both evacuation centers indicated that all the flood victims asserted that the better flood relief they received came from the federal government ruled by the party of Barisan Nasional (BN). Besides that, they also received relief from the state government ruled by the Parti Islam se-Malaysia (PAS). The types of relief were similar from both parties who delivered items such as rice, sugar, and biscuits, but from the view of the flood victims, BN seemed to provide better offer because they also provided money. The flood victims also mentioned that the relief from both political parties was still not enough. However, they still felt grateful because both governments still put an effort to help them.

Although the victims felt grateful with the relief that they received, most of the flood victims stated that they were not really satisfied with the means of delivering the relief because they felt that the remedies were just a strategy to gain the votes from them on the Election Day. It is because they experienced the flood disaster every year without solutions from the government.

\section{B. Political Beliefs}

From the individual interviews, data was collected from different political ideologies of the flood victims. The flood victims who believed in $\mathrm{BN}$ had a similar perception with those who believed in the PAS state government in terms of receiving the relief. Both sides mentioned that they will take relief from both governments. They believed that the relief is the responsibility of both governments to help them. Therefore, from who they received the reliefis not an issue. They will take each relief that isgiven to them.

Interestingly, even though they stated it was the responsibilities of the government, they still held their own beliefs. For the BN supporters, they remained in believing that their party is more capable than the opposition in distributing the relief and developing their area. In order to support this statement, they mentioned that the evidence can be seen from the relief that they are getting now, it shows that $\mathrm{BN}$ is better than PAS in providing flood relief.

PAS supporters, on the other hand, also remained with their own beliefs. The reason for that action is they believed that PAS state government did not have enough resources and allocation for giving more relief. They also believed that if PAS rules the federal government, they will get better than what they received now.

\section{Political Well-Being}

From the group discussions and individual interviews, the respondents mentioned that the relief that they receivedwas not enough to overcome the damage that they faced. The damage and destruction they encountered were more than the relief they received from both parties. However, the important things that made them satisfied and enhanced their well-being were the efforts by the politicians to come and show their concern for them. That is why they still hold on to their political beliefs toward their supporting parties.

BN and PAS supporters mentioned that they felt satisfied and happy when knowing their politicians came to mingle and give relief to all the flood victims at the evacuation 
centers. Furthermore, the visit by the Chief Minister of Kelantan without an announcement gained more trust and belief in the PAS supporters that the visit was sincere and honest. Due to that, even though they just received a little bit of relief, they still felt satisfied because of the efforts and concernsby the politicians of both political parties.

\section{Discussion}

Relief for the flood victims did not seem to give a high implication in changing the political beliefs among the flood victims. Flood victims did not put so much concern about the relief they received from both parties because there was only a slight difference in terms of relief. During the disaster, flood victims felt grateful for those who helped them even though it was just a little bit of help. They did not see whether their politicians could really overcome the problems and the situation of the disaster or not, but what they wanted was whether their politicians put an effort in order to help them as much as they could. Therefore, this finding indicates some similarities with the previous researches conducted by [5]-[7], [9]. It also indicates that the positive beliefs toward their politicians and parties make they feel satisfied with the relief and still feel grateful for whatever they received. Other than that, they also maintain their political beliefs.

These findings denied the " $5 \mathrm{C}+\mathrm{A}$ " dimension which asserted that people judge the authority and government in the disaster based on the capability, competency, credibility, compassion, correctness and anticipation. Without all of those criteria and only with compassion and effort by the politicians in both parties, it is already enough to satisfy the victims to still hold to their current political beliefs. In the developing countries and rural areas such as in Kelantan, the flood victims did not expect their government or politicians to handle or solve the flood problems. They think that the disaster that occurred cannot be avoided.

Therefore, sympathy and concern by the politicians are valued by the victims in making them still holding onto their political beliefs. In some circumstances, although the politicians have put a lot of effort in neutralizing a disaster, they are still not capable and competent in handling it due to the lack of resources, authorities or mechanisms. However, such effort shown by the politicians are valued by the victims rather than the politicians who have the full resources and authorities in handling the problems but lack in effort.

An interesting finding that makes this research distinct from the previous researches is that this research has proved that the positive political beliefs of the flood victims will enhance the individual well-being. Values of the efforts by the politicians make the victims satisfied with their politicians as well as increase their psychological well-being. By means of beliefs toward their political party and efforts shown by their politicians in lightening the burden of the flood victims create trust between the victims and the politicians. This mutual trust is the key to enhance the well-being of the victims. In simple words, the political beliefs will determine the well-being of the flood victims with the condition of effort by the politicians.

The aspect of well-being is beyond the material factor. It also consists of the psychological aspect such as political beliefs in determining the individual's well-being. Indeed the material aspect will enhance the economic well-being. Research conducted by [13] indicates that economic well-being is just a small portion of the criteria which are predictors of the psychological well-being. People who have low income also have a similar level of happiness and satisfaction equal to the people with high income. Therefore, to determine that by delivering adequate relief or materials to the flood victims will enhance their well-being is not a comprehensive standpoint.

There is a large gap in determining the psychological well-being rather than the economic aspect. Political support from the materials and the psychological aspect determine a more comprehensive well-being of the people [14]. However, the psychological aspect which is an intangible factor in determining the well-being of the disaster victims is often neglected in the government policy.

This study found that a positive impact on the political beliefs of the flood victims will enhance the quality of well-being of the flood victims in which political beliefs can become a remedy for the privation of relief, inadequate preparation in overcoming the flood disaster or the damage affected by the flood. However, politicians need to put into account that the flood victims will easily change their political beliefs and will punish them if they do not make an effort or take actions during disasters [8],[9].

In order to make the relief assistance more dynamic and comprehensive whether by the material or psychological aspect, the politicians and government need to use adequate philosophy in determining the shape in delivering the relief because it is not just giving the victims what they need but also love and support for the victims. As mentioned by Mecius[15],do not think about how to give benefits to the people but to think about how to be benevolent to the people. Based on that philosophy, the equilibrium between the materials and efforts in neutralizing the disaster can become more comprehensive. By doing so, the political belief aspect of the victims can also become a predictable factor in enhancing the psychological well-being of the flood victims.

\section{CONCLUSION AND RECOMMENDATIONS}

This paper demonstrates that the well-being of the flood victims is determined by their political beliefs. Inadequate preparation and the privation of reliefdo not really give such high implications in changing the political ideology of the flood victims. They tend to evaluate and see whether their politicians put an effort in handling the disaster rather than how much relief they received.

Therefore, this paper recommends future research to investigate the political beliefs of the flood victims in broader areas such as hazardous disasters that occur due to the development that has been done by the government. The degree of well-being among the hazardous disaster victims may differ from the well-being of flood victims who believe that the disaster is something that cannot be avoided.

\section{REFERENCES}

[1] R. Jervis, "Understanding beliefs," Political Psychology, vol. 27, pp. 641-663, 2006.

[2] P. A. Dawson, "The formation and structure of political belief system," Political Behavior, vol. 1, no. 2, pp. 99-122, 1979. 
[3] I. M. Wasserman, "Political beliefs and subjective indicators of quality of life," Social Indicators Research, vol. 11, no. 2, pp. 167-180, Aug 1982.

[4] A. S. Gerber, G. A. Huber, and E. Washington, "Party affiliation partisanship, and political beliefs: A field experiment," American Political Science Review, vol. 104, no. 4, pp. 720-744, Nov. 2010.

[5] D. Halpern, The Hidden Wealth of Nations, Cambridge, UK: Polity Press, 2010, pp. 30.

[6] F. G. Abney and L. B. Hill, "Natural disaster as a political variable: The effect of a hurricane on an urban election," The American Political Science Review, vol. 60, no. 4, pp. 974-981, Dec. 1966.

[7] K. Arceneaux and R. M. Stein, "Who is held responsible when disaster strikes? The attribution of responsibility for a natural disaster in an urban election," Journal of Urban Affairs, vol. 28, no. 1, pp. 43-53, 2006.

[8] J. T. Gasper and A. Reeves, "Make it rain? Retrospection and the alternative electorate in the context of natural disasters," American Journal of Political Science, vol. 55, no. 2, pp. 340-355, April 2011.

[9] A. Reeves, "Political disaster: Unilateral powers, electoral incentives, and presidential disaster declarations," The Journal of Politics, vol. 73, no. 4, pp. 1142-1151, Oct 2011

[10] R. S. Olson and V. T. Gawronski, "From disaster event to political crisis: A " $5 \mathrm{C}+\mathrm{A}$ " framework for analysis," International Studies Perspectives, vol. 11, no. 3, pp. 205-221, 2010.

[11] E. Basha and D. Rus, "Design of early warning flood detection systems for developing countries," in Proc. 2007 ICTD Conf., 2007, pp. 1-10.

[12] M. H. Shooshtary, L. Panaghi, and J. A. Moghadam, "Outcome of cognitive behavioral therapy in adolescents after natural disaster," Journal of Adolescent Health, vol. 42, no. 5, pp. 466-472, May 2008.

[13] R. J. Mullis, "Measures of economic well-being as predictors of psychological well-being," Social Indicators Research, vol. 26, no. 2, pp. 119-135, April 1992.

[14] M. Downie, R. Koestner, and S. N. Chua, "Political support for determination, wealth, and national subjective well-being," Motivation and Emotion, vol. 31, no. 3, pp. 174-181, 2007.
[15] P. B. Ebrey, A. Walthall, and J. B. Palais, Pre Modern East Asia: A Cultural, Social and Political History, vol. 1, Boston: Houghton Mifflin, 2009, pp. 28.

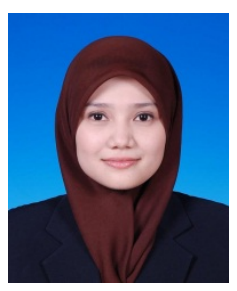

Noor Hadzlida Ayob was born at Kampung Balik Guar, Perlis, Malaysia on September 1, 1986. The author graduated with a Bachelor of Public Management and a Master of Public Management from Universiti Utara Malaysia, Sintok, Kedah in 2010 and 2012 respectively. The author is currently pursuing her Ph.D. at the same university and the major fields of her study are political science and political psychology.

She is currently a Research Assistant attached to the School of Multimedia Technology and Communication, Universiti Utara Malaysia. Prior to starting her Ph.D., she was employed as a Research Assistant at the Research and Innovation Management Center (RIMC) of the Universiti Utara Malaysia.

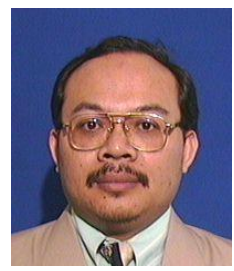

Mohd Fo'ad Sakdan was born in Muar, Johor, Malaysia on November 19, 1964. The author graduated with a B.A. and M.A. (Political Science) from Universiti Kebangsaan Malaysia in 1988 and 1990 respectively. The author obtained a Ph.D. in Conflict Management from University of Hull in 2006.

He possesses vast experience with more than 23 years of working experience in the field of politics. He joined Universiti Utara Malaysia as a tutor in 1989 and became a lecturer in 1992. He was also an associate professor attached to the College of Government, Law and International Studies (COLGIS), Universiti Utara Malaysia. Beside academic responsibilities, he has also held an administrative position as the Director of the Research and Innovation Management Center (RIMC) of the Universiti Utara Malaysia.

Assoc. Prof. Dr. Mohd Fo'ad Sakdan is now the Deputy Vice-Chancellor (Student Affairs and Alumni) of Universiti Malaysia Perlis. 